\title{
PHENOLOGICAL OBSERVATIONS OF SOME TREE SPECIES OF AKOT REGION, DISTRICT AKOLA (MAHARASHTRA)
}

\author{
Manik M.Dhore \\ Shri. Shivaji Arts, Commerce and Science College,Akot \\ E.mail dhoremanik739@gmail.com
}

\begin{abstract}
:
Phenology of tree species was studied in Akot region of Akola district during 2015 to 2017.Akola district is situated in Vidarbha region of Maharashtra state. Forest of this area is dry deciduous type. Phenology is the calendar of events in life history of plants. This paper deals with the study of phenological observations like leaf initiation, leaf fall, flowering and fruiting. The phenological information obtained in this study is mostly influenced by the season. Phenological observations are made of selected 16 tree species. Most of the species show flowering in the month of March- April. Leaf fall was maximum during the period from March-April. The peak period of maturation of fruit was May-June.
\end{abstract}

Keywords: Phenology, Tree, Flowering, Akot

\section{INTRODUCTION :}

Phenology is the study of the timing of the biological events in plants such as flowering, leafing and reproduction in relation to changes in season and climate. The life history of plant species involves seed germination, vegetative growth, flowering, fruit formation, seed maturation, seed dispersal and death. The study of phenology provides information and knowledge about the pattern of plant growth and the development as well as effect of environment and selective pressures on flowering and fruiting behaviour (Zhang et al.2006). Variation in flowering time relative to vegetative phenology induced by variety of factors like significant rain in winter or summer, decreasing or increasing photoperiod or drought induced leaf fall, results in a number of flowering patterns in tropical trees( Borchert et al.2002).Phenology of tree in any ecosystem and community determines the flowering periods which is indirectly dependent on the environmental variations(Rivera et al.2002, Hamann 2004,Zhang et al.2006). The main aim of this study was to analyse the different phenological events of some selected tree species in the dry deciduous forest. Here phenological observations were carried out on sixteen tree species of eight different families over a period of two years from January2015January2017.

\section{MATERIAL AND METHOD:}

The present study was carried out during the period January 2015 to January 2017 in Akot region. Akot town lies in the northernmost of the Akola district. Akola district lies in the western parts of the Vidarbha region of Maharashtra. Phenological observations were made of the selected tree species. Detailed observations were carried out at monthly intervals over a period of two years for each tagged tree. To study the phenology, leaf fall, duration of first and last flowering, new foliage and fruiting of selected plant species were recorded. Phenological observations were made on 16 plant species of Akot region.

Table 1 : Phenological observations of the Tree species of Akot region ,Akola District
\begin{tabular}{|l|l|c|c|c|c|}
\hline $\begin{array}{c}\text { S.N } \\
\cdot\end{array}$ & Name of species & Family & Leaf fall & Flowering & Fruiting \\
\hline 1 & Acacia nilotica & Mimosaceae & $\begin{array}{c}\text { February- } \\
\text { March }\end{array}$ & May -June & July-August \\
\hline 2 & Ailanthus excelsa & Simaroubaceae & $\begin{array}{c}\text { February- } \\
\text { March }\end{array}$ & February-March & May-June \\
\hline 3 & Azadirachta indica & Meliaceae & $\begin{array}{c}\text { February - } \\
\text { March }\end{array}$ & March- April & May-July \\
\hline 4 & Annona reticulata & Annonaceae & $\begin{array}{c}\text { March - } \\
\text { April }\end{array}$ & June-July & October- \\
November \\
\hline 5 & $\begin{array}{l}\text { Bauhinia } \\
\text { variegata }\end{array}$ & Caesalpiniaceae & $\begin{array}{c}\text { March- } \\
\text { April }\end{array}$ & January-March & March-May \\
\hline 6 & Bombax ceiba & Bombacaceae & $\begin{array}{c}\text { February- } \\
\text { March }\end{array}$ & January -March & February -April \\
\hline
\end{tabular}




\begin{tabular}{|c|c|c|c|c|c|}
\hline 7 & $\begin{array}{l}\text { Butea } \\
\text { monosperma }\end{array}$ & Papilionaceae & $\begin{array}{l}\text { January- } \\
\text { March }\end{array}$ & February -March & April -May \\
\hline 8 & Cassia fistula & Caesalpiniaceae & $\begin{array}{l}\text { February- } \\
\text { March }\end{array}$ & April -June & $\begin{array}{c}\text { July- } \\
\text { September }\end{array}$ \\
\hline 9 & Dalbergia sisso & Papilionaceae & $\begin{array}{l}\text { January- } \\
\text { February }\end{array}$ & March- April & May-July \\
\hline 10 & Delonix regia & Caesalpiniaceae & $\begin{array}{l}\text { February- } \\
\text { March }\end{array}$ & April-June & June-July \\
\hline 11 & $\begin{array}{l}\text { Erythrina } \\
\text { suberosa }\end{array}$ & Papillionaceae & $\begin{array}{l}\text { January - } \\
\text { February }\end{array}$ & March-April & May-June \\
\hline 12 & Ficus religiosa & Moraceae & $\begin{array}{l}\text { January- } \\
\text { February }\end{array}$ & April -May & May-June \\
\hline 13 & Helictres isora & Sterculiaceae & $\begin{array}{c}\text { March- } \\
\text { April } \\
\end{array}$ & July -September & $\begin{array}{l}\text { October - } \\
\text { January }\end{array}$ \\
\hline 14 & $\begin{array}{l}\text { Holoptelea } \\
\text { integrifolia }\end{array}$ & Ulmaceae & $\begin{array}{c}\text { February - } \\
\text { March }\end{array}$ & February -March & March-April \\
\hline 15 & Melia azedarach & Meliaceae & $\begin{array}{l}\text { January- } \\
\text { February }\end{array}$ & $\begin{array}{l}\text { November- } \\
\text { December }\end{array}$ & $\begin{array}{l}\text { February- } \\
\text { March }\end{array}$ \\
\hline 16 & Pongamia pinnata & Papillionaceae & $\begin{array}{l}\text { February- } \\
\text { March }\end{array}$ & April-May & May -July \\
\hline 17 & $\begin{array}{l}\text { Semecarpus } \\
\text { anacardium }\end{array}$ & Anacardiaceae & $\begin{array}{c}\text { February - } \\
\text { March }\end{array}$ & $\begin{array}{c}\text { September- } \\
\text { November }\end{array}$ & $\begin{array}{l}\text { January- } \\
\text { February }\end{array}$ \\
\hline 18 & Tectona grandis & Verbenaceae & $\begin{array}{l}\text { February- } \\
\text { March }\end{array}$ & August-October & $\begin{array}{c}\text { December- } \\
\text { January }\end{array}$ \\
\hline 19 & Terminalia catapa & Combretaceae & $\begin{array}{l}\text { January - } \\
\text { February }\end{array}$ & March-April & June-October \\
\hline 20 & Terminalia arjuna & Combretaceae & $\begin{array}{l}\text { January- } \\
\text { February }\end{array}$ & May-June & July-August \\
\hline
\end{tabular}

\section{RESULT AND DISCUSSION:}

Twenty tree species with thirteen different families were selected for Phenological study in Akola district of Maharashtra. From the present phenological study it was observed that the annual phenological cycle starts from leaf fall phase followed by blossoming phase. The seasonal activity in dry deciduous tree of study area in general is more conspicuous in summer month. The peak time for flowering was observed in last week of February to March in six plant species Ailanthus excelsa, Butea monosperma, Erythrina suberosa, Bombax ceiba, Dalbergia sisoo and Holoptelea integrifolia . In some tree species like Cassia fistula and Tectona grandis flowering phase is remarkably prolonged. Fruiting was observed mostly in month of May to June in most of the tree species. Leaves fall were maximum in between month of January to March in most of the species. Initiation of leaf and phase of fruiting takes place either subsequently or simultaneously.

\section{REFERENCES:}

Borchert, R., G. Rivera, W. Haynauer (2002). Modification of vegetative phenology in a tropical semi -deciduous forest by abnormal drought and rain. Biotropica, 34: 27-39

Hamann, A. (2004). Flowering and fruiting phenology of a Phillipine submontane rain forest: Climatic factors as proximate and ultimate causes.J.Ecol.92:24-31

Rivera, G. S. Elliott, L. S. Caldes ,G. Nicolossi, V.T.R. Coradin, R.Borchert (2002). Increasing day length induces spring flushing of tropical dry forest trees in the absence of rain.Trees Struct.Funct. 16:445-456

Zhang, G. M., Q. S. Song, D. R. Yang (2006). Phenology of Ficus racemosa in Xishuagbanna, Southwest China.Biotropica.38: 334-341 